\title{
The Compliance Cost of Taxing Foreign-Source Income: Its Magnitude, Determinants, and Policy Implications
}

\author{
MARSHA BLUMENTHAL \\ University of St. Thomas, St. Paul, MN 55105 \\ JOEL B. SLEMROD \\ School of Business Adminstration, The University of Michigan, Ann Arbor, MI 48109-1234
}

\begin{abstract}
This paper uses survey evidence to estimate the compliance cost of the U.S. system of taxing foreign-source income. The evidence suggests that this cost is about 40 percent of the total tax-compliance cost of large U.S. corporations, which is disproportionately higher than the aggregate share of assets, sales, and employment that is abroad. It is also very high compared to the revenue raised by the United States from taxing foreign-source income, although this comparison must be qualified because arguably a principal purpose of this system is to protect U.S. revenues collected on domestic-source income. The disproportionate compliance cost of foreign-source income is not apparent in a survey of European-based multinational corporations.
\end{abstract}

Key words: taxation, compliance costs, multinational corporations

There is ample anecdotal evidence that the United States' system of taxing the foreignsource income of its resident multinationals is extraordinarily complex, causing the companies considerable cost to comply with the system, complicating long-range planning decisions, reducing the accuracy of the information transmitted to the Internal Revenue Service (IRS), and even endangering the competitive position of U.S.-based multinational enterprises. This paper uses data from three recent surveys of multinational enterprises to assess quantitatively these claims. Specifically, its goals are threefold: to estimate the magnitude of the cost of complying with the U.S. system of taxing foreign-source income, to investigate the determinants of these costs, including both aspects of the firm's operations and aspects of the tax system and, finally, to discuss the policy implications of the findings.

\section{Total tax compliance costs of big business}

Before focusing on the tax-compliance costs due to foreign-source income, we begin by summarizing what is known about the overall tax-compliance costs of big business. ${ }^{1}$ The most comprehensive study of this topic was carried out by these authors as part of a project of the Office of Tax Policy Research (OTPR) of the University of Michigan Business School, based on a 12-page survey sent to the tax officers of the 1,672 firms in the Coordinated 
Examination Program (CEP) of the Internal Revenue Service. Firms are selected into the CEP on the basis of several criteria, of which size and the expected resource cost of an examination are primary; 58 percent of the CEP firms have assets in excess of $\$ 1$ billion. For most of the CEP firms, the IRS conducts a team examination of the tax return each year. ${ }^{2}$ Because the CEP includes firms with unresolved past filings, regardless of their current business status, a number of these firms were not active entities in 1992. From the 1,329 firms that were active, we received 365 completed surveys, for a response rate of 27.5 percent. $^{3}$

The survey instrument, which was drafted with the assistance of a panel of corporate tax officers, had five parts. ${ }^{4}$ General characteristics of a company's tax affairs, its industry or sector, measures of firm size, and the extent of its foreign operations were explored in Part 1. Parts 2 and 3 concerned the costs of complying with the income tax laws. Respondents were asked to apportion these costs along several dimensions: whether due to federal or to state income taxation, whether due to personnel or nonpersonnel expenditures, whether personnel expenditures were for salaries inside the firm's tax department, for salaries in other departments, or for fees to outside advisers, and whether expenditures were for record keeping, research, or one of eight other functions. The fourth part examined the firm's interactions with the Internal Revenue Service, and the final part posed open-ended questions about the sources of complexity in the tax code, suggestions for simplifying it, and the strategies adopted in order to deal with greater complexity.

Table 1 presents the estimated compliance cost of both the entire CEP sample and a weighted subsample of the respondents constructed to represent the Fortune 500.5 The esti-

Table 1. Average compliance cost (in thousands of dollars).

a. All Responding Firms

\begin{tabular}{|c|c|c|c|c|c|}
\hline \multirow[b]{2}{*}{ Function } & \multicolumn{2}{|c|}{ Federal } & \multicolumn{2}{|c|}{ State and Local } & \multirow[b]{2}{*}{ Total } \\
\hline & $\begin{array}{c}\text { Tax } \\
\text { Department }\end{array}$ & $\begin{array}{c}\text { Other } \\
\text { Departments }\end{array}$ & $\begin{array}{c}\text { Tax } \\
\text { Department }\end{array}$ & $\begin{array}{c}\text { Other } \\
\text { Departments }\end{array}$ & \\
\hline Within-firm personnel & $\$ 476.8$ & $\$ 130.6$ & $\$ 217.8$ & $\$ 70.3$ & $\$ 895.5$ \\
\hline Within-firm nonpersonnel & 163.9 & 123.2 & 76.6 & 58.5 & 422.2 \\
\hline Outside firm & \multicolumn{2}{|c|}{190.1} & \multicolumn{2}{|c|}{57.3} & 247.4 \\
\hline Total & \multicolumn{2}{|c|}{$\$ 1,084,6$} & \multicolumn{2}{|c|}{$\$ 480.5$} & $\$ 1,565.1$ \\
\hline
\end{tabular}

b. Fortune 500 Only

\begin{tabular}{|c|c|c|c|c|c|}
\hline \multirow[b]{2}{*}{ Function } & \multicolumn{2}{|c|}{ Federal } & \multicolumn{2}{|c|}{ State and Local } & \multirow[b]{2}{*}{ Total } \\
\hline & $\begin{array}{c}\text { Tax } \\
\text { Department }\end{array}$ & $\begin{array}{c}\text { Other } \\
\text { Departments }\end{array}$ & $\begin{array}{c}\text { Tax } \\
\text { Department }\end{array}$ & $\begin{array}{c}\text { Other } \\
\text { Departments }\end{array}$ & \\
\hline Within-firm personnel & $\$ 615.3$ & $\$ 160.0$ & $\$ 291.3$ & $\$ 82.0$ & $\$ 1,149.5$ \\
\hline Within-firm nonpersonnel & 236.0 & 183.8 & 103.8 & 94.6 & 618.2 \\
\hline Outside firm & \multicolumn{2}{|c|}{269.7} & \multicolumn{2}{|c|}{73.0} & 342.7 \\
\hline Total & \multicolumn{2}{|c|}{$\$ 1,465.7$} & \multicolumn{2}{|c|}{$\$ 644.7$} & $\$ 2,110.4$ \\
\hline
\end{tabular}

Source: Slemrod and Blumenthal (1993). 
mated average annual cost for a CEP firm was $\$ 1.57$ million, totaling $\$ 2.080$ billion for all 1,329 firms. ${ }^{6}$ In the weighted Fortune 500 subsample, each firm spent an average of $\$ 2.11$ million complying with federal and subfederal income taxes. Aggregating to all Fortune 500 firms, this corresponds to a total compliance cost of $\$ 1.055$ billion. For both samples and in round numbers, 70 percent of this total was due to federal income tax, with the remainder due to state and local income taxes. Fifty-five percent of the expenditures are devoted to within-firm personnel, while 30 percent are spent on nonpersonnel purchases and 15 percent go to outside advisers. Considering only the within-firm expenditures, 70 percent are incurred inside the tax department, the remainder in other, nontax departments.

An alternative way of describing the magnitude of compliance costs is to compare them to the revenues raised. The most recent data available for the 1989 CEP firms, indicates a total federal income tax liability of $\$ 54.4$ billion. Since our estimate of federal income tax compliance costs for CEP firms is $\$ 1.440$ billion (approximately 70 percent of $\$ 2.080$ billion), the cost-to-revenue ratio, neglecting the timing disparity, is 2.6 percent. A similar calculation, for state income taxes, shows that compliance costs account for a somewhat higher 5.6 percent of the revenues raised. Over all levels of government, our cost-to-revenue ratio estimate is 3.2 percent. This is lower than the cost-to-revenue ratio of 5 to 7 percent that has been estimated for the individual income tax (Slemrod and Sorum, 1984; Blumenthal and Slemrod, 1992).

In order to explore the functional distribution of compliance costs, the survey defines ten categories of activities that absorb the efforts of firm personnel: record keeping, research, planning, dealing with others, filing the return, audits, appeals, litigation, preparing information for financial statements and monitoring the tax process. The breakdown of costs into these areas is presented in Table 2. For employees working within a firm's tax department, filing returns commands the largest share of compliance costs, about 30 percent. Audits, planning, and research each contribute an additional 10 percent and record keeping adds just under 10 percent. Costs that are attributed to the work of employees in other departments (within the firm) are heavily accounted for by record keeping (about 50 percent). Another 15 percent of these costs go toward preparing information for financial statements. Most of these large firms also hire outside consultants for tax matters. About 80 percent of external advising expenditures are devoted to five functions: planning, litigation, research, appeals, and audits. Looking at this in a slightly different way, more than half of all of the tax litigation and appeals work is done externally. These findings suggest a strong division of labor in compliance activities: tax department personnel specialize in filing returns, while personnel in other departments do the record keeping, and outside consultants concentrate on litigation and planning.

Regarding the factors determining compliance cost, our analysis suggests that firm size plays an important role. While larger firms (measured by assets, sales, or employment) experience larger compliance costs, there are clear economies of scale since the average cost per unit of size decreases as size increases. Primary industry or sector also matters. Our results suggest that costs are higher for firms engaged in mining and in oil and gas exploration and production; they seem to be lower for firms in wholesale and retail trade. Several other characteristics appear to contribute significantly to higher compliance costs. These include the existence of multiple active entities, being subject to the alternative minimum tax or California income tax, and the presence of ongoing appeals or litigation. 
Table 2. Average functional expenditures by location of activity.

\begin{tabular}{|c|c|c|c|c|c|}
\hline \multirow[b]{2}{*}{ Function } & \multicolumn{2}{|c|}{ Within the Firm } & \multirow[b]{2}{*}{$\begin{array}{c}\text { Outside } \\
\text { Assistance }\end{array}$} & \multirow[b]{2}{*}{ Total } & \multirow[b]{2}{*}{$\begin{array}{l}\text { Percentage o } \\
\text { Total Costs }\end{array}$} \\
\hline & $\begin{array}{c}\text { Tax } \\
\text { Department }\end{array}$ & $\begin{array}{c}\text { Other } \\
\text { Departments }\end{array}$ & & & \\
\hline Record keeping & $\$ 69.5$ & $\$ 115.7$ & $\$ 4.2$ & $\$ 189.4$ & $15.9 \%$ \\
\hline Research & 75.4 & 8.3 & 42.7 & 126.4 & 10.6 \\
\hline Planning & 88.1 & 12.6 & 49.6 & 150.3 & 12.6 \\
\hline Dealing with other personnel & 52.8 & 14.7 & 8.4 & 75.9 & 6.4 \\
\hline Filing returns & 215.1 & 20.1 & 17.7 & 252.9 & 21.3 \\
\hline Audits & 89.5 & 17.3 & 29.7 & 136.5 & 11.5 \\
\hline Appeals & 25.4 & 3.7 & 30.8 & 59.9 & 5.0 \\
\hline Litigation & 14.0 & 2.0 & 48.0 & 64.0 & 5.4 \\
\hline \multicolumn{6}{|l|}{ Preparing information for } \\
\hline financial statements & 41.2 & 32.8 & 6.0 & 80.0 & 6.7 \\
\hline Monitoring tax process & 36.1 & 7.5 & 6.0 & 49.6 & 4.2 \\
\hline Other & 0.0 & 0.0 & 3.8 & 3.8 & 0.3 \\
\hline Total & $\$ 707.0$ & $\$ 234.6$ & $\$ 246.8$ & $\$ 1,188.7$ & $100 \%$ \\
\hline
\end{tabular}

b. Fortune 500 Only

\begin{tabular}{|c|c|c|c|c|c|}
\hline \multirow[b]{2}{*}{ Function } & \multicolumn{2}{|c|}{ Within the Firm } & \multirow[b]{2}{*}{$\begin{array}{l}\text { Outside } \\
\text { Assistance }\end{array}$} & \multirow[b]{2}{*}{ Total } & \multirow[b]{2}{*}{$\begin{array}{l}\text { Percentage of } \\
\text { Total Costs }\end{array}$} \\
\hline & $\begin{array}{c}\text { Tax } \\
\text { Department }\end{array}$ & $\begin{array}{c}\text { Other } \\
\text { Departments }\end{array}$ & & & \\
\hline Record keeping & $\$ 78.8$ & $\$ 136.1$ & $\$ 1.4$ & $\$ 216.3$ & $13.7 \%$ \\
\hline Research & 101.8 & 11.8 & 64.6 & 178.2 & 11.3 \\
\hline Planning & 124.3 & 17.3 & 84.0 & 225.6 & 14.3 \\
\hline Dealing with other personnel & 64.9 & 25.1 & 10.7 & 100.7 & 6.4 \\
\hline Filing returns & 283.8 & 37.2 & 17.1 & 338.1 & 21.4 \\
\hline Audits & 121.0 & 29.1 & 31.4 & 181.5 & 11.5 \\
\hline Appeals & 32.0 & 4.5 & 35.7 & 72.2 & 4.6 \\
\hline Litigation & 19.6 & 2.8 & 69.4 & 91.8 & 5.8 \\
\hline \multicolumn{6}{|l|}{ Preparing information for } \\
\hline Monitoring tax process & 51.3 & 11.2 & 12.1 & 74.6 & 4.7 \\
\hline Other & 0.0 & 0.0 & 3.0 & 3.0 & 0.2 \\
\hline Total & $\$ 926.2$ & $\$ 313.7$ & $\$ 336.8$ & $\$ 1,576.7$ & $100 \%$ \\
\hline
\end{tabular}

Source: Slemrod and Blumenthal (1993).

Note: These figures do not include within-firm nonpersonnel costs. All figures, except for those in the last column are in thousands of dollars.

\section{The compliance cost of doing business abroad}

In addition to assessing the magnitude and determinants of overall compliance costs, the OTPR survey included a question focusing on the fraction of the costs associated with their operations that generate foreign-source income. Respondents were asked, "What fraction of the total compliance cost due to the federal corporate income tax were due to foreign- 
source income?"7 From the responses to this question, we calculate that 39.2 percent of the total compliance cost of federal taxes is due to foreign-source income $e^{8}$ (43.7 percent for the Fortune 500 sample).

Are these percentages disproportionately high relative to the companies' foreign activities? The simple answer to that question is yes, based on a comparison of 39.2 percent to the fraction of either assets abroad (21.1 percent), sales abroad (24.1 percent), or employment abroad (17.7 percent). For the Fortune 500 companies, 43.7 percent is higher than the fractions of assets, sales, and employment abroad, which are $27.8,30.1$, and 26.2 percent, respectively. ${ }^{9}$

Another estimate of the importance of foreign-source operations for compliance costs comes from a 1993 survey of the twenty-four companies in the International Tax Policy Forum (ITPF); of the twenty-four members, seventeen responded to the survey. The respondents consist of some of the largest multinationals in the United States, with average worldwide assets in 1991 of $\$ 74.2$ billion. These companies' estimated average annual compliance cost with the federal and state corporation income tax systems came to $\$ 13.04$ million. The average costs due to foreign operations came to $\$ 4.66$ million. Assuming that 70 percent of the total compliance cost (equal to $\$ 9.13$ million) was due to the federal system, 51.0 percent of these costs were due to foreign-source income; this figure is quite close to the $\mathbf{4 5 . 5}$ percent figure obtained from the OTPR survey's Fortune 500 sample. These companies report that the average tax due on foreign-source income, net of foreign tax credits, was \$55.14 million, so that compliance cost represented 8.5 percent of net revenue. This number is significantly higher than the ratio for compliance costs as a whole determined from the OTPR survey.

Some more insight into the relationship between compliance costs and foreign presence can be gained from examining Figures 1 through 3 . These scatterplots show, for firms from the OTPR survey with a foreign presence, the fraction of federal compliance cost due to foreign-source income (percent foreign compliance costs) (PFC) against the three measures of foreign presence discussed above-percent foreign assets (PFA), percent foreign sales (PFS), and percent foreign employment (PFE), respectively. Inspection of these figures reveals that significantly more observations lie above the diagonal than lie below it, which is consistent with the claim that foreign-source operations are associated with a higher compliance cost than their relative importance would suggest.

How foreign-source income contributes to compliance cost can be explored more closely by estimating the curve that best fits these data. For the data in each of the three figures we estimate the best-fitting cubic relationship ${ }^{10}$ that goes through the two endpoints of the diagonal; these estimated relationships are shown in the figures. In all cases the best-fitting curve starts out above the diagonal but then crosses it at a fraction of foreign presence of about 40 percent. This pattern is consistent with there being significant fixed costs for foreign operations, so that when foreign operations make up considerably less than half of the company's operations, they account for a disproportionate cost of the tax operation. Once the firm is a truly global operation, economies of scale in dealing with foreign tax matters are achieved.

There are two reasons not to be satisfied with this analysis. First of all, it relies on the answer to one question (about the fraction of costs due to foreign-source income), the answer to which is enormously complex and subtle. The answers provided are thus more 


\section{Compliance Costs and Foreign Assets}

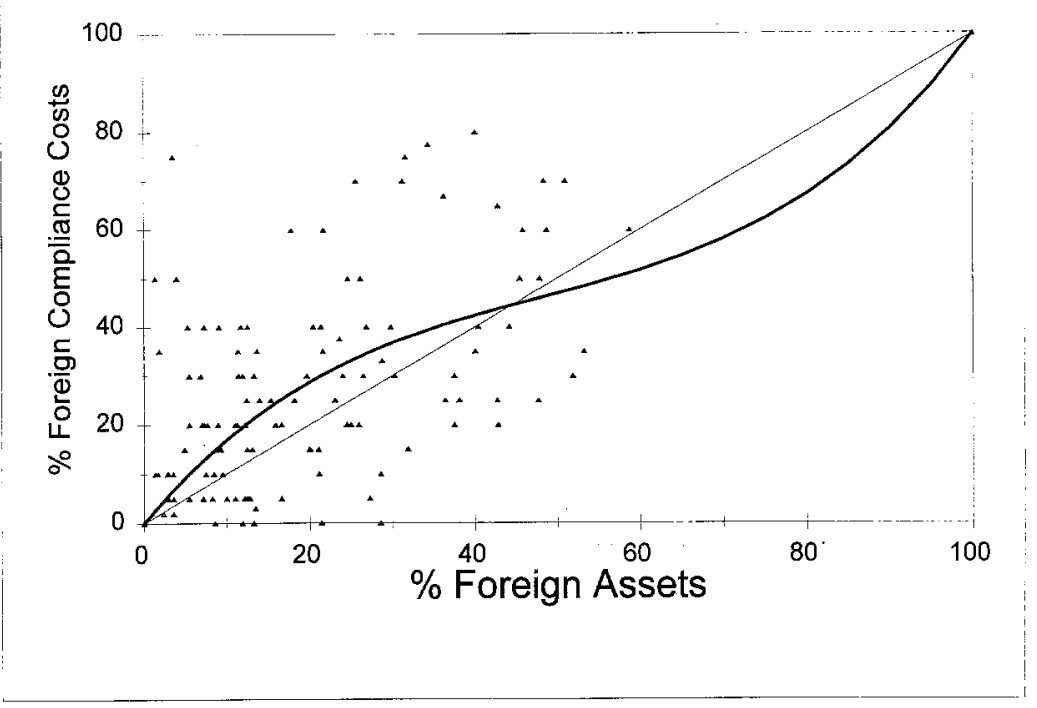

Figure 1. Compliance costs and foreign assets.

\section{Compliance Costs and Foreign Sales}

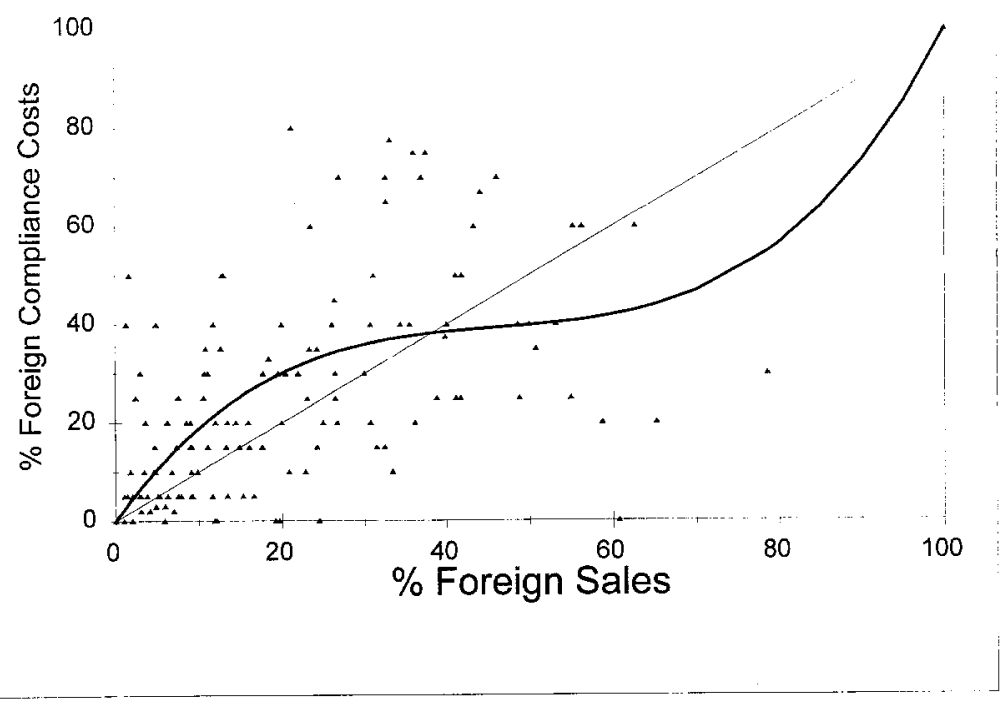

Figure 2. Compliance costs and foreign sales. 


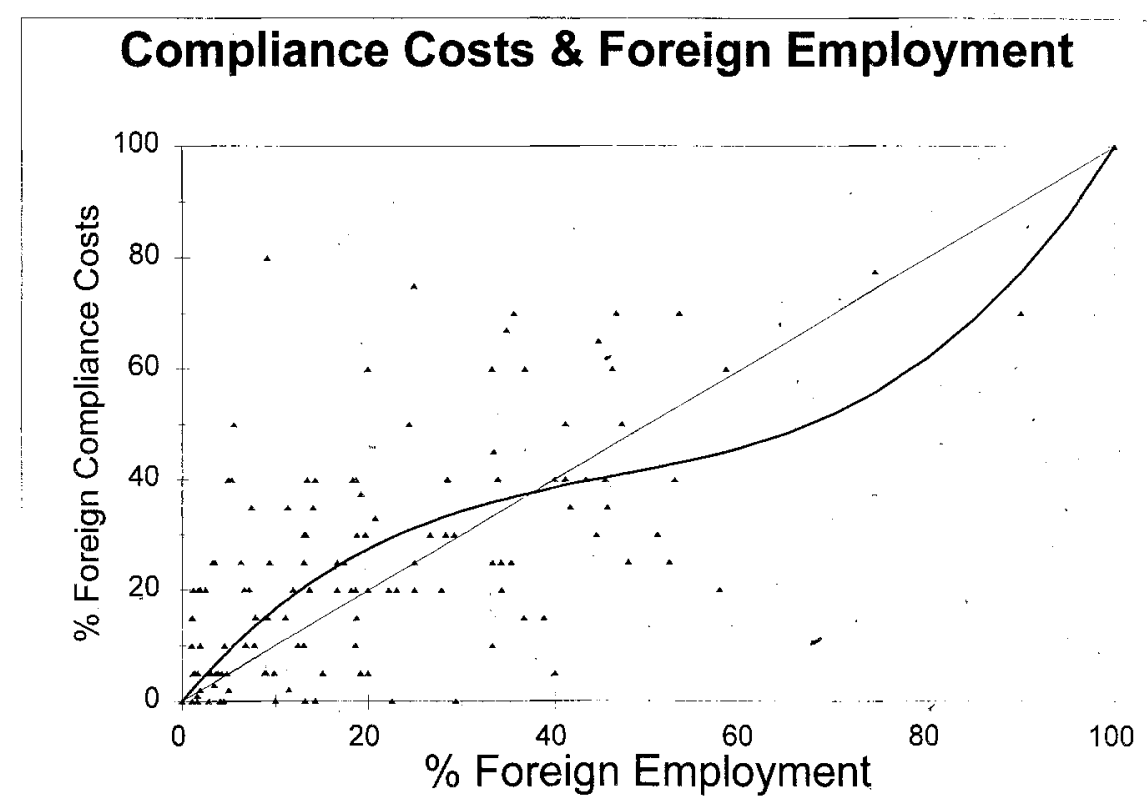

Figure 3. Compliance costs and foreign employment.

impressionistic than most of the other answers to the survey and therefore subject to more error. The second reason is a purely statistical one. To the extent that there are errors in the answer to this question, there is good reason to suspect that they are not purely whitenoise errors that would not affect the estimated best-fitting curve. When the true answer is a low percentage of compliance costs (say, 10 percent), there is much more scope for an error on the high side than for an error on the low side; where the answer is a high percentage of compliance costs (say, 90 percent), there is much more scope for an error on the low side than on the high side, where the answer is bounded by 100 percent. This will produce bias in the estimated relationship.

Both of these problems are avoided by an analysis of the relationship between total compliance costs, worldwide size, and the fraction of operations abroad. If, holding worldwide size constant, more globally oriented firms have higher compliance costs, this suggests that the compliance costs of foreign operations is higher than that of domestic operations. Table 3 displays the results of three multiple regression analyses of (the logarithm of) total compliance costs as a linear function of (the logarithm of) each of three measures of global size as well as the three measures of foreign presence.

In each of the three cases the estimated coefficient on the foreign-presence ratio is positive and statistically significant, suggesting again that the compliance costs of foreign operations are higher than that of domestic operations. For example, the interpretation of the coefficient on the ratio of total employment that is abroad, 0.0065 , is as follows: for a firm of given worldwide size, as measured by total employment, shifting employment abroad 
Table 3. Results of regression analyses of the relationship between total compliance costs, size, and the extent of foreign activity.

\begin{tabular}{lccc}
\hline $\begin{array}{c}\text { Indicator of World } \\
\text { Size and Percentage } \\
\text { Foreign }\end{array}$ & $(1)$ & $(2)$ & $\begin{array}{c}(3) \\
\text { Employment }\end{array}$ \\
\hline Independent Variables: & & & \\
Intercept & 2.32 & 2.78 & 5.65 \\
& $(0.32)$ & $(0.39)$ & $(0.11)$ \\
Worldwide size & 0.568 & 0.502 & 0.410 \\
& $(0.045)$ & $(0.054)$ & $(0.049)$ \\
Percentage foreign & 0.0120 & 0.0098 & 0.0065 \\
& $(0.0041)$ & $(0.0044)$ & $(0.0042)$ \\
$R^{2}$ & 0.630 & 0.496 & 0.366 \\
Number of observations & 125 & 123 & 158 \\
Mean of dependent variable & 6.591 & 6.597 & 6.530 \\
\hline
\end{tabular}

Note: The dependent variable is the logarithm of internal personnel costs plus expenditures on outside assistance. Standard errors are in parentheses below the coefficient estimates. In column (1), world wide assets is measured by the logarithm of worldwide assets, and percentage foreign is measured by the ratio of foreign assets to worldwide assets. Similar definitions apply to columns (2) and (3). Analyses of columns (1) and (2) exclude financial and insurance firms.

to raise the foreign ratio by ten percentage points will increase total compliance costs by 6.5 percent.

These two different analytical approaches suggest that the compliance costs of foreignsource operations are disproportionately high compared to either the foreign share of assets, sales, or employment-that is, holding size constant, costs are higher with greater foreign presence. It would also be of interest to know whether the compliance costs are disproportionately high compared to foreign-source income, but that information is not available from either survey.

Perhaps of most interest is the ratio of foreign-income-related compliance costs to the revenue raised by the U.S. Treasury from foreign-source income. Because most of the tax otherwise due to the U.S. Treasury on foreign-source income is offset by foreign tax credits, the net tax paid to the U.S. government is small relative to foreign-source income. Recall that in the survey of ITPF firms, the cost-to-revenue ratio for foreign-source income was 8.5 percent. This contrasts with the OTPR survey result, for all CEP firms, that the federal cost-to-revenue ratio, for both domestic and foreign income, was 2.6 percent. Indeed, recent work by Grubert and Mutti (1995) suggests that the compliance cost-to-revenue ratio for foreign-source income may be even higher than 8.5 percent; their results indicate that, although total foreign-source income in 1990 was $\$ 89.7$ billion, the net tax paid to the U.S. government on that income was only $\$ 4.6$ billion. This implies that the ratio of aggregate compliance cost to aggregate net revenue raised is very high.

This conclusion must be interpreted very cautiously, however, because arguably the objective of our foreign-source income provisions is to protect the revenue appropriately levied 
on domestic-source income. The argument is that, in the absence of a strict (and perhaps inevitably somewhat complex) regime for limiting foreign tax credits, multinational companies could offset domestic-source income with foreign tax credits. Even in a territorial system, under which foreign-source income is exempt from U.S. taxation, rules about the sourcing of income would have to be enforced in order to defend the U.S. revenue base. This suggests that it would be appropriate to compare the compliance costs of foreign operations not to the net revenue directly attributable to these operations, but rather to the net revenue (on both domestic-source and foreign-source income) that would be foregone if a radically simpler system were to be instituted. We discuss this issue in Section 6.

\section{What characteristics of foreign business operations contribute to compliance costs?}

In this section we use multiple regression analysis to search for the particular characteristics of foreign business operations that contribute to compliance costs, holding constant other determinants of cost such as principal sector, the scale of operations, and domestic tax characteristics. The results may be found in Table 4, where the dependent variable is the logarithm of foreign compliance costs. Of the characteristics studied, only the number of

Table 4. Results of regression analysis of what characteristics of foreign business operations contribute to foreign compliance costs.

\begin{tabular}{lrc}
\hline \multicolumn{1}{c}{ Independent Variables } & Estimated Coefficient & Standard Error \\
\hline Constant & 8.3114 & 0.8335 \\
Foreign assets & -0.0712 & 0.1656 \\
Foreign employment & -0.1390 & 0.1653 \\
Foreign sales & 0.8305 & 0.2256 \\
Industry: mineral & 1.6242 & 0.8596 \\
Industry: trade & -0.9758 & 0.7505 \\
Number of majority-owned foreign subsidiaries & 0.0100 & 0.0056 \\
Number of countries in which a subsidiary is located & -0.0039 & 0.0125 \\
Number of branches & -0.0881 & 0.0699 \\
Number of countries in which a branch is located & 0.0670 & 0.0862 \\
Foreign sales corporation & 0.1363 & 0.3334 \\
Section 936 corporation & 0.0744 & 0.3855 \\
Foreign joint venture & -0.0023 & 0.0039 \\
Foreign parent & 0.2566 & 0.5686 \\
$R^{2}$ & 0.6932 & \\
\hline
\end{tabular}

Note: $n=64$.

Dependent variable: logarithm of foreign compliance cost (expenditures on salaries within the firm and on outside tax consultants, multiplied by the percentage of compliance costs attributed to foreign-source income).

Foreign assets, foreign employment, and foreign sales are defined as logarithms.

Industry: mineral is a dummy variable, equal to 1 if the firm is engaged in mining or oil and gas and 0 otherwise.

Industry: trade is a dummy variable, equal to 1 if the firm is engaged in either wholesale or retail trade and 0 otherwise.

Foreign sales corporation is a dummy variable, equal to 1 if the firm has one and 0 otherwise.

Section 936 corporation is a dummy variable, equal to 1 if the firm has one and 0 otherwise.

Foreign joint venture is a dummy variable, equal to 1 if the firm is engaged in one and 0 otherwise.

Foreign parent is a dummy variable, equal to 1 if the firm has a foreign parent, and 0 otherwise. 
majority-owned subsidiaries had a statistically significant effect (at a 90 percent confidence level); each additional subsidiary is associated with a 1 percent increase in the compliance costs of foreign-source income.

\section{What features of the U.S. Tax Code contribute to the compliance costs of foreign operations?}

The previous section addressed what characteristics of foreign business operation contribute to compliance cost. In this section we address what features of the U.S. Tax Code contribute to compliance cost. These are, of course, related questions because a possible reason that a particular characteristic of business operations adds to compliance cost is the way the tax system is structured.

This important question cannot be answered quantitatively with the OTPR survey results, however, because all of the firms face the same statutes. Because there is no variation in the applicable tax law statutes across companies, there is no way to assess the compliancecost impact of altering certain statutes. This would require an analysis of compliance cost over time as tax law changed.

In the absence of quantitative measures of the cost of particular aspects of the tax code, we must be content with the qualitative response to questions about tax complexity. One of the OTPR survey questions asked, "What aspect(s) of the current tax code is/are most responsible for the cost of complying with the federal corporate income tax code?" International issues were widely cited. Ninety-three respondents mentioned at least one foreignrelated area, while 212 had either a minority or majority interest in a foreign affiliate or had a foreign branch. Of the ninety-three, forty-four merely mentioned "international" or "foreign" as the tax code aspect causing complexity, without citing a specific section code. Table 5 provides a breakdown of the most commonly mentioned code sections that were identified. The foreign tax credit heads the list with thirty-seven mentions, including nine who singled out the requirement that income sources be segregated into "baskets," for which distinct foreign tax credit calculations must be made. Information reporting on foreigncontrolled corporations on Form 5471 came second, with twenty-one limitations, followed by the rules governing the sourcing of income (seventeen), and transfer pricing issues in Section 482 (sixteen).

Table 5. Most cited areas of complexity in taxing foreign-source income.

\begin{tabular}{llc}
\hline Rank & \multicolumn{1}{c}{ Tax Aspect } & Number of Mentions \\
\hline 1 & Foreign tax credit & 37 \\
2 & Information reporting on controlled foreign corporations (Form 5471) & 21 \\
3 & Determination of source of income (Sections 861 through 865) & 17 \\
4 & Transfer pricing (Section 482) & 16 \\
5 (tie) & Subpart F & 5 \\
5 (tie) & Form 5472 & 5 \\
7 (tie) & Foreign sales corporation requirements & 4 \\
7 (tie) & Foreign ownership provisions (Section 6038A) & 4 \\
\hline
\end{tabular}

Source: OTPR Survey.

Note: Other tax code aspects mentioned: branch profits tax, look-through rules, PFIC rules, foreign currency rules (Section 986), possessions corporation credit (Section 936). 


\section{Do high compliance costs put U.S. multinational enterprises at a comparative disadvantage with foreign multinationals?}

Conventional wisdom holds that not only is the U.S business tax system very complex but also that it is more complex than the systems imposed by other countries. Unfortunately, it is impossible to quantitatively assess the conventional wisdom because comparable studies of the tax-compliance costs of big business for other countries do not exist. Although there have been excellent studies of the business tax-compliance cost in other countries, none of these studies has focused on the largest companies, making a meaningful cross-country comparison impossible. For example, the business sample in the United Kingdom used by Sandford, Godwin and Hardwick (1989) contained only two companies with more than 500 employees and only six with more than 100 employees. In their study of Australia, Pope, Fayle, and Chen (1991) report having sixty-seven firms with over 1,000 employees, and seventy-seven with annual turnover (sales) exceeding $\$ 100$ million. For the latter group.of companies they estimate annual mean compliance costs to be $\mathrm{A} \$ 56,896$, compared to mean tax payable of $A \$ 1,760,000$; this amounts to 3.2 percent of tax revenue. Any comparison of these numbers to the U.S. case should note the much smaller average size of the Australian sample.

There is one informative recent study of note, however. This study was commissioned by the committee of experts formed by the European Commission (EC) in 1990 to investigate whether the commission should institute proposals to harmonize corporation taxes within the EC. One of the questions posed to this committee, known informally as the Ruding Committee after its chairman Onno Ruding, was to what extent differences in business taxation cause major distortions with respect to investment decisions and competition.

To help answer this question, the committee commissioned a survey of businesses in all the European Community and five European Free Trade Association countries; 965 responses were received, representing a response rate of just over 11 percent. The median turnover of the responding companies was $£ 38.5$ million for all companies, and $£ 281.5$ million for those identified as parent companies of multinational groups. Slightly more than two-thirds of the respondents were in the industrial sector, with the remainder split among retail, financial services, nonfinancial services, and other.

One section of the survey dealt with the compliance and tax-planning costs associated with international taxation as opposed to domestic taxation. The respondents were asked, separately for domestic income and foreign-source income, to estimate tax compliance costs as a percentage of the actual income flows. The distribution of responses is displayed in Table 6. It is clear that for most companies compliance costs represent a small fraction of both domestic- source and foreign-source income. More than 85 percent of respondents estimate the cost to represent less than 3 percent of either source of income. More significantly, there is no evidence that the compliance-cost ratio is higher for foreign-source compared to domestic income. Almost exactly the same percentage of firms put the costs less than 1 percent in both cases; 85.2 percent of the respondents assess the cost to be less than 3 percent for foreign-source income, compared to 87.1 percent for domestic-source income. Our estimates of the average-compliance-cost-to-income ratio for all respondents are also very similar-1.69 percent for foreign-source income compared to 1.74 percent for domestic-source income..$^{11}$ Thus, contrary to our findings about U.S. multinationals, 


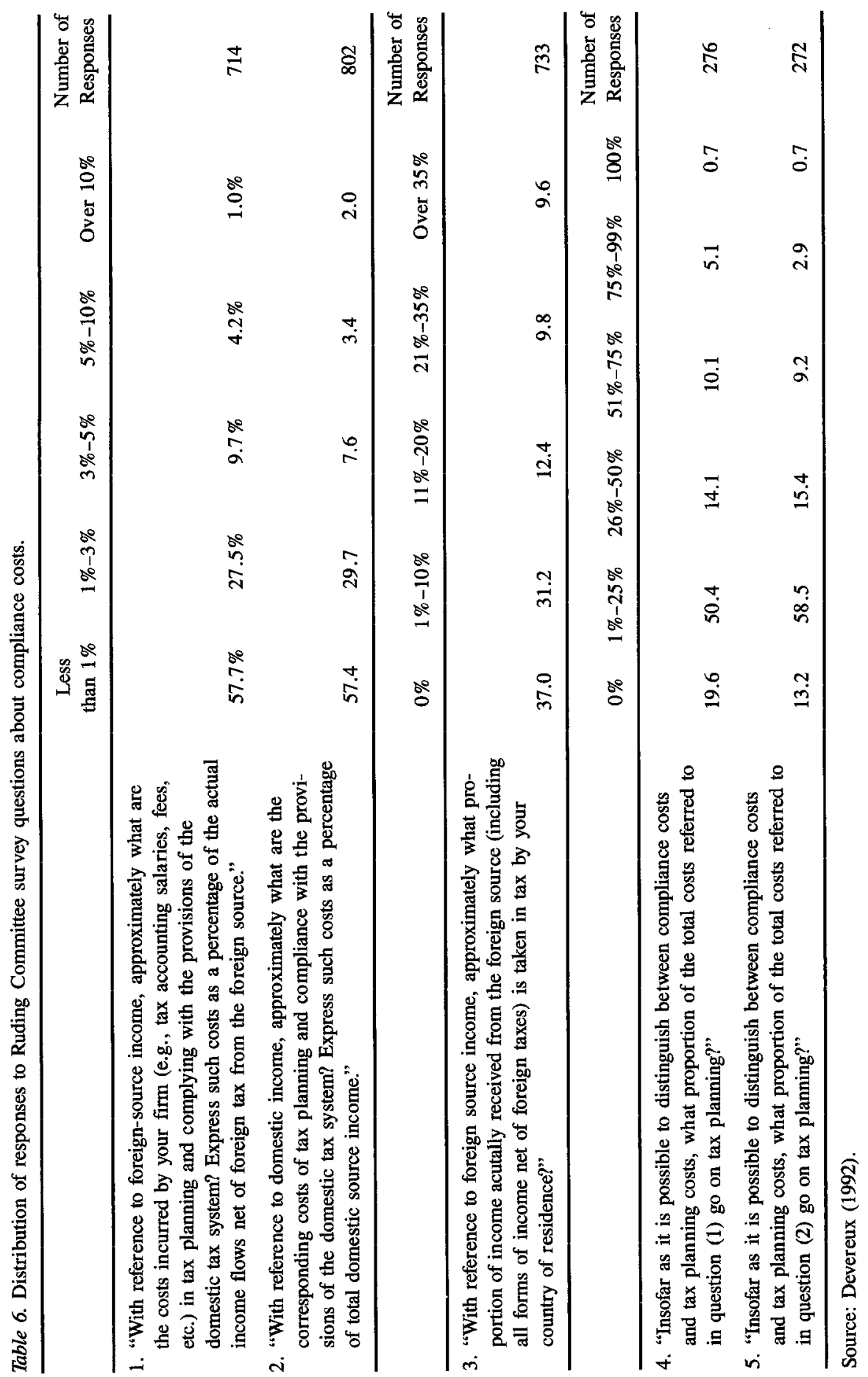


data from the Ruding Committee survey suggests that, for foreign multinationals, compliance costs relative to income are no higher for foreign operations than they are for domestic operations.

We can also use the Ruding Committee survey responses to do a very broad comparison of the compliance cost relative to income of U.S. versus European multinationals. The OTPR survey estimated the total compliance cost to be 3.2 percent of taxes paid. Using a combined federal and state corporate tax rate of 41 percent implies that the ratio of cost to income would be 1.3 percent of income, compared to 1.7 percent for the European multinationals. This comparison ought to be treated with great caution, due to the quite different survey methodologies employed in the two studies.

The third question in Table 6 concerns the effective tax rate on foreign-source income levied by the home country. The answer is zero for 37 percent of the respondents (presumably including all of those headquartered in countries that operate a territorial tax system), and the average response is estimated to be 11.2 percent. The final two questions refer to what fraction of total compliance costs are devoted to tax planning. A majority of firms placed that answer between 1 and 25 percent. The distribution of responses to this answer is not markedly different for domestic-source versus foreign-source income.

\section{What tax changes would reduce compliance cost in a significant way?}

For policy purposes, as important as the level and determinants of compliance costs is the direction of promising reform to reduce those costs. Of course, minimal compliance costs is by no means the only, or even overriding, objective of a tax system. Nevertheless, we believe it is helpful to identify those aspects of the tax code that, according to corporate tax officers, would provide significant cost savings.

This question was asked directly in both the OTPR and ITPF surveys. In the OTPR survey, the tax officers were asked, "What suggestions would you make to simplify compliance with the tax (system) at either the federal or state/local levels?" Answers were thus not limited to foreign-source income.

Of those suggestions related to foreign-source income, simplification of the foreign tax credit was by far the most often recommended suggestion. Also cited specifically were the allocation-of-expense rules- Form 5471 for reporting of controlled foreign corporation activity and Section 482 on transfer pricing. A few mentioned more radical proposals such as moving to a territorial system of taxation and eliminating deferral. The distribution of responses is detailed in Table 7 .

A question about desirable simplifications was also put directly to the ITPF member companies, specifically: "What, if any, specific revisions of the U.S. Internal Revenue Code would you suggest to reduce the cost of complying with U.S. rules regarding the taxation of foreign-source income?" They were asked to list up to three suggestions, and, for each suggestion, the respondent was asked to estimate the saving in the total compliance cost of foreign-source income from enacting these revisions.

The twelve companies that responded to this question came up with twenty-nine suggestions. The specific revision mentioned most often (by six firms) was to measure the earnings and profits of foreign affiliates using book income for financial accounting purposes. 
Table 7. Foreign-source tax simplification most often suggested by corporate tax officers.

\begin{tabular}{llc}
\hline Rank & \multicolumn{1}{c}{ Reform } & Mentions \\
\hline 1 & Simplify foreign tax credit, including reducing number of baskets & 13 \\
2 (tie) & Simplify allocation rules & 4 \\
2 (tie) & Eliminate or simplify Form 5471 & 4 \\
4 (tie) & Allow safe havens for transfer policy & 3 \\
4 (tie) & Eliminate deferral & 3 \\
6 (tie) & Simplify Subpart F & 2 \\
6 (tie) & Eliminate pooling of dividends for calculating foreign tax credit & 2 \\
\hline
\end{tabular}

Source: OTPR Survey.

\begin{tabular}{llc}
\hline Rank & \multicolumn{1}{c}{ Reform } & Mentions \\
\hline 1 & $\begin{array}{l}\text { Use U.S. book income for accounting purposes to measure the earnings and } \\
\text { profits of foreign affiliates }\end{array}$ & 6 \\
2 & Allow conversion of foreign taxes using annual exchange rate & 4 \\
3 & Simplify foreign tax credit baskets & 3 \\
4 & Simplify information reporting on foreign affiliates (Form 5471) & 2 \\
\hline
\end{tabular}

Source: ITPF Survey.

The average percentage saving estimated for these six companies was 2.5 percent. Other suggestions mentioned more than once were to allow conversion of foreign taxes using an annual average exchange rate (four mentions); to eliminate or simplify (by reducing to only an active and passive basket) the foreign tax credit baskets (three mentions); and to simplify information reporting on foreign affiliates on Form 5471 (two mentions).

Concern over the costs of complexity, and suggestions for reducing it, have come recently not only from the business community. A prominent tax lawyer, David R. Tillinghast (1991), has remarked ruefully "that since 1962, at least, the Internal Revenue Code has been hopelessly and often needlessly complicated in its application to international transactions-to the point where it is doubtful whether the law can be administered or, even given the desire to do so, complied with" (p. 190). He goes on to carefully evaluate the simplification potential of both incremental and fundamental reforms of the U.S. system of taxing foreign-source income. We consider here only the simplification potential of fundamental reform options.

Tillinghast first considers the rules governing which foreign-source income is taxed on accrual and which income is eligible for deferral. He concludes that the most effective simplification would be a complete termination of deferral, although he notes that it would simplify "by giving the victory to the tax collector" (p. 195). Note, though, that given the current U.S. tax rate of 35 percent and the ability to average income of many kinds from many countries, the estimated revenue pickup from eliminating deferral may be quite small. Although considerable simplification could be achieved by taking the opposite route of unlimited deferral, because this is unlikely to be applied to passive investment rules to distinguish passive and active income would have to be retained. 
With regard to the relief of double taxation, Tillinghast asserts that the simplest system is one that is anathema to business on other grounds - the deduction system. Allowing taxpayers to deduct without limit foreign taxes as an expense rather than claiming a credit would eliminate the need to define foreign income taxes and the need to compute any limitation on the allowance and would allow simplification of provisions dealing with foreign losses. Deductibility combined with an elimination of deferral would render irrelevant the allocation of expenses between domestic and foreign income within a controlled group and would eliminate the incentive to generate low-taxed foreign income.

Tillinghast rejects deductibility because of its adverse impact on foreign direct investment and its international unacceptability, and goes on to consider other reform options. He considers a type of exemption system, under which passive income would be taxed on an accrual basis but active business income of foreign-source would be exempt from U.S. taxation. Tillinghast concludes that this system "would accomplish some, but not a remarkable amount of simplification" (p. 211). Although there would be no need for a foreign-tax-credit mechanism for active income, it would still be necessary to sort income into U.S. and foreign source and then into the exempt category and foreign tax credit category. Expenses would still have to be allocated and apportioned.

A recent U.S. Treasury Department (1993) study also considered the simplification potential of major reform options. It first considered what was called a "modified exemption" system. Under this system, active foreign-source business income subject to a substantial rate of foreign tax, or earned in a country that generally applies a substantial rate of tax, would be exempt from U.S. taxation; passive income and active income not subject to high enough foreign tax would be subject to U.S. tax, probably on a current basis, and allowed a foreign tax credit. The Treasury concluded that the simplification potential of a modified exemption system would depend on the manner in which it were implemented, in particular how precise was the method used in identifying exempt income.

The Treasury also considered the elimination of deferral-that is, the taxation of all foreignsource income on a current basis. As with the modified exemption system, they concluded that the simplification potential depends largely on how exactly it is implemented. It would simplify compliance by eliminating the need to distinguish, as under current law, income eligible for deferral and income subject to current taxation. Additional complexity would depend on whether it was implemented by using the Subpart F method by giving foreign affiliates domestic corporation treatment or by using the branch method.

\section{Summary}

The main points of this investigation can be summarized as follows:

1. The overall income tax compliance costs of large U.S. companies are substantial, averaging over $\$ 2$ million annually for a Fortune 500 firms or $\$ 1.5$ million for a typical business subject to the IRS large-case audit program. Relative to the revenues collected, however, these costs are smaller than individual income tax compliance costs-3.2 percent compared to 5 to 7 percent. 
2. About 40 percent of the costs of complying with the federal income tax are due to foreignsource income. This figure exceeds the share of assets, sales, or employment abroad, suggesting that the foreign-source income compliance costs are disproportionately high relative to their role in the activities of the corporation.

3. The compliance costs of foreign-source income may be extremely high relative to the revenue raised by the U.S. government on this income. However, to the extent that the system of taxing foreign-source income is meant to protect the tax base on domesticsource income, this ratio is not particularly meaningful.

4. According to corporate tax officers, the most costly features of the U.S. system of taxing foreign-source income are the foreign tax credit and the information reporting on controlled foreign corporations.

5. In contrast to the results reported here for U.S. multinationals, data from the Ruding Commission study suggest that, for European multinationals, compliance costs relative to income are no higher than they are for domestic operations.

6. Two careful recent studies have concluded that fundamental reforms of the U.S. international tax system could reduce compliance costs substantially, but how much savings could be achieved depends on the details of how these reforms are implemented.

\section{Acknowledgments}

We thank Jean Funfar, Michael Keen, Peter Merrill, and two referees for helpful comments on an earlier draft.

\section{Notes}

1. For the purposes of this paper, compliance cost refers simply to gross expenditures by firms on tax matters. To what extent compliance costs represent a burden to the firm, or a resource cost to the country, is discussed at length elsewhere (Sandford, Godwin, and Hardwick, 1989). Certainly some portion of these costs, (such as those devoted to tax planning) is incurred voluntarily and likely yields a net positive return to the firm. These costs then do not represent a privately borne burden but do nevertheless constitute a burden on society, as the resources represented by the cost have alternative uses. Because the costs are tax-deductible, the net cost to the firm is lower than the gross figure presented here and the social cost.

There are also social costs to tax complexity that are not included in our figures and are difficult to quantify. Complexity inevitably introduces a capriciousness of tax burdens and in particular may confer an advantage to firms whose corporate culture is open to exploiting opportunities for expected tax reduction.

2. The survey methodology is described in detail in Slemrod and Blumenthal (1993). The OTPR survey, and the ITPF survey discussed later, are available upon request from the authors.

3. This response rate is low enough that there is a potential for response bias. The following analysis makes no correction for this, except in the construction of a reweighted sample representing the Fortune 500. Even in this case, the reweighting is related to size and not to any other firm characteristic that may be correlated with the compliance costs of taxation. We do know, though, that the sectoral and asset-size distribution of the respondent population matches quite closely to the distribution of the CEP firms (see Slemrod and Blumenthal, 1993).

4. The survey was accompanied by a letter stating the objectives of the research-to construct a baseline estimate of the magnitude of costs of complying with the corporate income tax and to identify the determinants of these costs-and promising anonymity. 
5. The reweighting procedure divided, by ranking, the Fortune 500 into ten groups of fifty firms; the weighting factors applied to each firm was fifty divided by the number of firms in the group of fifty in the respondent sample.

6. This represents a slight increase in real costs compared to the estimates done for 1986 by Arlinghaus and Anderson (1986).

7. In the cover letter accompanying the survey, respondents were asked to include the expenditures of foreign affiliates resulting from U.S. tax laws and to exclude expenditures incurred due to foreign tax laws.

8. Note that the 39.2 percent does not represent an average of the reported percentages. Instead it is 100 times the ratio of total costs due to foreign source income to total overall costs.

9. In all of the results reported in this section and thereafter, financial firms are excluded from analyses of assets and sales and included in analyses of employment. With the exception of Table 4 (which includes a dummy variable for the presence of a foreign parent), we also deleted from the sample all foreign-owned firms. Tables 1 and 2 refer to all firms in the sample; eliminating foreign-owned firms increases the average compliance cost figures in these tables only slightly.

10. To be precise, we estimated three ordinary least-squares regressions of the following form: $y=a_{0} x+a_{1} x^{2}+$ $a_{2} x^{3}$, where $a_{0}+a_{1}+a_{2}$ was constrained to equal one. The regression results were as follows, with standard errors in parentheses:

$$
\begin{array}{rlrl}
P F C= & 1.99 P F A-3.20 P F A^{2}+2.21 P F A^{3} & R^{2}=0.346, n=195 \\
& (0.24) \quad(0.91) & (0.69) & \\
P F C= & 2.33 P F S-4.79 P F S^{2}+3.47 P F S^{3} & R^{2}=0.349, n=189 \\
& (0.21) \quad(0.76) \quad(0.56) & \\
P F C= & 2.00 P F E-3.64 P F E^{2}+2.64 P F E^{3} & R^{2}=0.378, n=243
\end{array}
$$

Note that, because the cubic is constrained to go through $(0,0)$, including these observations in the regression analysis has no effect on the estimates.

11. These averages in this section are obtained from the distributions presented in Devereux (1992) by assuming the average value of each range, 0.5 percent for the "less than 1 percent" category, 15 percent for the "over 10 percent" category, and 50 percent for the "over 35 percent" category.

\section{References}

Arlinghaus, Barry P., and Donald T. Anderson. (1986). "The Organization and Operation of the Tax Function of Large Corporations: A 1986 Update." The Tax Executive, Summer.

Blumenthal, Marsha, and Joel Slemrod. (1992). "The Compliance Cost of the U.S. Individual Tax System: A Second Look After Tax Reform." National Tax Journal, 45(2) June, 85-202.

Blumenthal, Marsha, and Joel Slemrod. (1994). "The Compliance Costs of the U.S. Corporate Income Tax for Large Corporations." Proceedings of the 86th Annual Conference of the National Tax Association, National Tax Association, Columbus, $\mathrm{OH}, 32-35$.

Devereux, Michael. (1992). "The Impact of Taxation and International Business: Evidence from the Ruding Committee Survey." Keele University Department of Economics Working Paper 92-10, May.

Grubert, Harry, and John Mutti. (1995). "Taxing Multinationals in a World with Portfolio Flows and R\&D: Is Capital Export Neutrality Obsolete?" International Tax and Public Finance, forthcoming.

Pope, Jeff, Richard Fayle, and Dong-ling Chen. (1991). The Compliance Costs of Public Companies' Income Taxation in Australia, 1986-7. Sydney: Australian Tax Research Foundation.

Sandford, Cedric, Michael Godwin, and Peter Hardwick. (1989). Administrative and Compliance Costs of Taxation. Bath, U.K.: Fiscal Publications.

Slemrod, Joel, and Marsha Blumenthal. (1993). "The Income Tax Compliance Cost of Big Business." University of Michigan, Office of Tax Policy Research Working Paper 93-11, July.

Slemrod, Joel, and Nikki Sorum. (1984). "The Compliance Cost of the U.S. Individual Tax System." National Tax Journal, 37(4) March, 461-74.

Tillinghast, David R. (1991). "International Tax Simplification." American Journal of Tax Policy, 8(2), 187-247. U.S. Department of Treasury. (1993). "International Tax Reform: An Interim Report." Washington, DC, January 15. 